\title{
Research and Practice of Teaching Method on Balanced Development of Listening, Speaking, Reading, and Writing Ability
}

\author{
Song $\mathrm{Hu}$ \\ School of Foreign Languages, Dalian Jiaotong University, Dalian, 116021, China
}

\begin{abstract}
Cultivating students' listening, speaking, reading, and writing ability is always regarded as an effective method of China's college English teaching reform. Through analysis on input and output theory of second language acquisition and under combination of current situation of China's college students' English learning, this paper points out the important significance of balanced development of these four abilities. Meanwhile, the teachers' role change can play an active role in promoting students' balanced development of four abilities.
\end{abstract}

Key words: listening, speaking, reading, and writing ability; balanced development; teaching method

\section{Overview}

The listening, speaking, reading, and writing ability involves students' listening, oral expression, reading, and writing ability. Essentially, to cultivate students' these four abilities is to cultivate students' ability to input and output language information in the brain. The four skills are related with each other, have mutual effect, and make mutual promotion and improvement. The listening and reading ability are the basis of speaking and writing ability; on the contrary, the speaking and writing ability are the representation of improvement in listening and reading understanding ability. Under current environment that China advocates quality-oriented education, the English teaching must take cultivate students' listening, speaking, reading, and writing ability as an important teaching goal. After the balanced development of these four abilities is realized, it is able to make students improve their ability to flexibly apply English to communicate with others and cultivate the new-era talents with comprehensive quality.

The language input and output theory is always a problem which attracts key attention in research on second language acquisition. As early as in 1970s 1980s, the famous linguists Krashen and Swain proposed Input Hypothesis and Output Hypothesis. Krashen thought that the language acquisition could happen only when the language acquirer accepted "Comprehensive Input", that is, second language input slightly higher than his current language skill level, and he could focus attention on meaning understanding rather than formal understanding. In other words, if the language learner currently has a level of "i”, we shall provide the input of level "i+1". Generally speaking, while the language learners accept input, due to limited memory capacity, they will abandon language upon understanding the content for the convenience of accepting new language information. Therefore, a problem is proposed for foreign language educators: how to make students pay attention to linguistic form, process the language, and then absorb language, and finally improve language input level. It can be seen that the language input is actually the key and necessary condition for language acquisition, but not the only factor. In 1985, Swain proposed "Comprehensive Output", and he thought that the learners should have chance to use the language they learnt except for necessary comprehensive input so that it was possible to reach fluent level similar to native speakers. In other words, the learners shall apply the language resources they have obtained; after obtaining the practice chance of "Comprehensive Output", they can enhance 
and consolidate the content they have learnt. Without input, the learners will gain nothing; without output, the learners will be unable to truly master the language due to lack of practice. Therefore, the learners can realize the goal of flexibly applying the language only after there is a virtuous cycle of input and output under balanced state.

\section{Research status}

With continuous deepening of foreign language teaching reform, more and more scholars and research personnel start to pay attention to cultivating college students' listening, speaking, reading, and writing ability. In past 10 years, hundreds of relevant papers have been published in about 10 kinds of foreign language core journals in China. Those papers respectively give a discussion on how to improve college students' English comprehensive utilization ability, explains the relation among listening, speaking, reading, and writing ability, and analyze current situation of China's college English teaching. Those academic papers make a great contribution to China's foreign language teaching reform.

\section{Research objective and research content}

Over a long time, there always exist the problems in China's foreign language teaching, such as “examination-oriented”, "time-consuming and low-efficiency”, and "dumb English",[7]; although China always continuously borrows ideas from successful experience of other countries and launches a series of new foreign language teaching reform measures, many students' foreign language comprehensive ability still remains at middle or low level.

This paper aims at changing traditional duck-stuffing teaching method and using input and output theory to guide English teaching. Over many years, we always adopt old teaching mode, that is, the teachers make continuous instructions and blackboard-writing in classroom, and the teaching method is single and boring. With the development of modern science and technology, the multimedia and network have provided students with sound and images in teaching process, which more or less makes up some deficiencies in traditional teaching means. Therefore, the teachers are not pure classroom dominators, but shall become the guiders for students' language learning. While the attention is paid to language input, the more attention shall be paid to students' language output process. We can specifically divide English teaching into three steps, that is, before learning, in teaching process, and after teaching. Specifically speaking, while the teachers carry out curriculum design, they can make full use of current teaching materials related to listening, speaking, reading, and writing courses; in the classroom teaching and in the process of students' independent learning before and after classroom teaching, the teachers shall input information with reasonable capacity to students, and guide students' language learning in a diversified way. The listening ability shall be practiced together with speaking ability, and the reading ability shall be practiced together with writing ability so that they can promote each other and it is able to achieve the balance of four abilities. In the design of teaching program, the teachers shall pay attention to form diversification of language information input, select the information with suitable difficulty and suitable capacity, seek for the method through which the students can store information well, and help to guide students to actively digest the information input by teachers in classroom and consciously store and process the information after class so that the students can effectively express their thoughts in oral or writing way, fluently communicate with others, and realize balanced language input and output. 


\section{Research value and practical significance}

The application of input and output theory into specific English listening, speaking, reading, and writing course teaching can timely and effectively change the traditional language input form, and make learners realize a balanced language input (listening and reading) and output (speaking and writing) in whole teaching process so as to promote students' integrated development of all skills in English learning and improve students' language comprehensive utilization ability. The college English is a required course that each college student shall learn for at least two years. How to stimulate students' interest in foreign language learning within limited classroom time, and how to utilize the advantage that college students have flexible and sufficient extracurricular disposable time to encourage them to carry out independent learning and exploring learning so as to realize the true value of English learning are of great practical significance for English teaching of our school and even for China's overall foreign language teaching reform.

\section{Conclusion}

Although it is stipulated in College English Curriculum Requirements published in 2007: "The teaching objective of college English is to cultivate students' English comprehensive application ability so that they can effectively use English to carry out oral and written information exchange in later study, work, and social contact, as well as to enhance their independent learning ability, and improve comprehensive literal quality to adapt to the demand of China's social development and international communication." ${ }^{\text {[4] }}$, the teachers' classroom teaching still remains at elementary stage of instructing language knowledge, and the teachers only apply grammar translation method to guide teaching in practice. The unreasonable quality and quantity of input information and the single input form result in great problems in students' information input process. Although the application of grammar communicative approach is emphasized in English teaching in later teaching reform, another extreme appears in specific operation process, that is, the students' mutual communication occupy whole classroom time and the information output far exceeds the information input. However, this teaching method integrated with the advantages of grammar translation method and communicative approach applies input and output theory to guide the innovation mode of college English teaching; while the attention is paid to quantity and quality of language input, the attention is also paid to output of language information so as to realize balanced development of students' listening, speaking, reading, and writing ability and make students' English learning form a virtuous cycle.

Nowadays, as more and more attention is paid to balanced development of various abilities in English learning, the transition of teacher's role is also worth our research and discussion. In old teaching mode, the teachers are the subject of classroom; after class, there lacks of communication between college teachers and students. It is obvious that this condition is neither good for balanced development of students' language ability, nor good for forming a virtuous cycle of language input and output. Therefore, this paper advocates that the students shall become the subject of classroom; after class, the teachers shall become the guider to guide students to carry out independent learning. Furthermore, the teaching shall become "education"; while the teachers improve their quality, the teaching shall be able to educate students and make them realize an integrated development. 


\section{References}

[1]Krashen,S. Pvinciples and Practice in the Language Classroom. Oxford: Pergamon, 1982.

[2]Swain, M.Communicative Competence: Some roles of compresible input and comprehensible in its development〔M〕. Rowley. MA: Newbury House:1985.

[3] Liu Runqing: English Educational Research [M], Background: Foreign Language Education and Research Press, 2004.

[4] Department of Higher Education of Ministry of Education: College English Curriculum Requirements [Z], Shanghai Foreign Language Education Press, 2007.

[5] Wen Qiufang: Three Basic Problems on Tracking Study of Second Language Acquisition: Classification, Design, and Possibility [J], Foreign Language in China, 2009 (2): p54-60.

[6] Luo Lisheng: Krashen's Language Input Theory and Foreign Language Teaching [J], Tsing Hua Journal of Chinese Studies, 2001 (4).

[7] Hu Zhuanglin: "Low-efficiency” Problems in China’s English Teaching [J], Foreign Language Teaching, 2002 94): p3-7.

[8] Xiang Maoying: Influence of Emotional Factors on College English Teaching, Foreign Languages and Their Teaching, 2003 (3): p23-26.

[9] Cai Jigang: Several Thoughts on College English Teaching [J], Foreign Language Teaching and Research, 2005 (2).

[10] Ding Yanren: Research on Second Language Acquisition and Foreign Language Learning [J], Shanghai Foreign Language Education Press, 2004. 